\title{
DIET OF EARED DOVES (Zenaida auriculata, AVES, COLUMBIDAE) IN A SUGAR-CANE COLONY IN SOUTH-EASTERN BRAZIL
}

\author{
RANVAUD, R., ${ }^{1}$ FREITAS, K. C. de, ${ }^{2}$ BUCHER, E. H., ${ }^{3}$ DIAS, H. S., ${ }^{4}$ AVANZO, V. C. ${ }^{1}$ and \\ ALBERTS, C. C. ${ }^{5}$ \\ ${ }^{1}$ Instituto de Ciências Biomédicas, Universidade de São Paulo, Avenida Lineu Prestes, 1524, CEP 05508-900, \\ São Paulo, SP, Brazil \\ ${ }^{2}$ Instituto de Biociências, Universidade de São Paulo, Rua do Matão, 321, Travessa 14, CEP 05508-900, \\ São Paulo, SP, Brazil \\ ${ }^{3}$ Centro de Zoologia Aplicada, Universidad de Córdoba, Casilla de Correos 122, Córdoba 5000, Argentina \\ ${ }^{4}$ Centro de Desenvolvimento do Vale do Paranapanema (CDVale), Rua Hermes R. da Fonseca, 1180, \\ CEP 19800-000, Assis, SP, Brazil \\ ${ }^{5}$ Faculdade de Ciências e Letras, Universidade Estadual Paulista, Avenida Dom Antonio, 2100, \\ CEP 19800-000, Assis, SP, Brazil \\ Correspondence to: Ronald D. Ranvaud, Instituto de Ciências Biomédicas, Universidade de São Paulo, Avenida \\ Lineu Prestes, 1524, CEP 05508-900, Cidade Universitária, São Paulo, SP, Brazil, e-mail: ranvaud@usp.br \\ Received June 20, 2000 - Accepted August 17, 2000 - Distributed November 30, 2001
}

(With 8 figures)

\begin{abstract}
Farmers in the Paranapanema Valley (São Paulo, Brazil) have reported problems with flocks of Eared Doves (Zenaida auriculata) eating sprouting soybeans. In this region these birds breed colonially in sugar-cane, and eat four crop seeds, using $70 \%$ of the dry weight, in the following order of importance: maize, wheat, rice, and soybeans. Three weeds (Euphorbia heterophylla, Brachiaria plantaginea, and Commelina benghalensis) were important. This information suggests that the doves adapted particularly well to the landscape created by the agricultural practices in the region, exploiting many available foods.
\end{abstract}

Key words: diet, colonial breeding, sugar-cane, Eared Dove, Zenaida.

\section{RESUMO}

\section{Dieta de pombas Zenaida auriculata (Aves, Columbidae) de uma colônia em um canavial do Sudeste brasileiro}

Agricultores no médio Vale do Paranapanema têm relatado problemas com bandos de pombas (Zenaida auriculata) que se alimentam de cotilédones de soja na época do plantio. Na região do município de Tarumã, SP, essas aves se reproduzem em uma colônia situada em um canavial, e sua dieta é composta de 70\% do peso seco por 4 grãos cultivados (em ordem de importância: milho, trigo, arroz e soja). As sementes de três invasoras (Euphorbia heterophylla, Brachiaria plantaginea e Commelina benghalensis) são importantes. Essa informação sugere que as pombas se adaptaram particularmente bem à paisagem criada pelas práticas agrícolas da região, aproveitando vários alimentos oferecidos.

Palavras-chave: dieta, reprodução colonial, cana-de-açúcar, pomba, Zenaida.

\section{INTRODUCTION}

As previously seen in other South American countries (Murton et al., 1974; Valencia et al.,
1976; for a review see Bucher, 1990), in the past 30 years Eared Doves (Zenaida auriculata) have increased dramatically in some regions of SE Brazil. Large breeding colonies have developed, 
notably in sugar-cane plantations, a novel breeding habitat, briefly described in the literature (Rezende, 1987a, b, c; Bucher, 1990; Donatelli et al., 1995).

Farmers in the 1980's increasingly reported damage to crops, mostly to emerging soybean seedlings. Problems also occurred in rice and wheat plantations, particularly due to the impact of large flocks landing on the crops shortly before and during harvest time. Control measures caused heated debates, given that Brazilian wildlife protection laws do not permit killing of doves (Federal law \# 5.197, of 1967). A massive but ineffective official management program based on collecting eggs and nestlings (Ranvaud, 1999a) was carried out between January 1993 and August 1994.

Understanding the feeding ecology of the Eared Dove is an essential first step not only in evaluating potential agricultural damage but also as a key to understanding this particular population outbreak. Diet may also determine migratory and breeding patterns (Lack, 1968; Murton \& Westwood, 1977; Bruggers \& Elliott, 1989), even though little is known about these aspects of dove life history in the region. There are two distinct yearly breeding peaks (Feb-May and Aug-Nov) with repeated broods in the same location (Menezes et al., 1998). This resembles colonial patterns in Cordoba, Argentina (Bucher \& Orueta, 1977), but is different from those of single-clutch itinerant colonies in North-eastern Brazil (Aguirre, 1976; Bucher, 1982). Murton et al. (1974), Bucher \& Orueta (1977), and Bucher (1990) speculate that reproduction is triggered by favourable environmental conditions, especially adequate availability of certain food items. Bucher (1990) has also suggested a close relationship between land-use, food supply, and Eared Dove outbreaks, particularly in the case of the Argentinean Chaco. There, the expansion of agriculture in previously uncultivated savannahs led to year-round availability of sorghum and other cultivated crops (in order of importance: millet, wheat, maize, and peanuts), paving the way for Eared Dove population expansion.

The main goals of this study were: a) to determine the diet of the Eared Doves at the large Tarumã colony, São Paulo, Brazil, over a full year cycle; b) to compare this information with what is known for the species elsewhere; c) to relate this information to the life history of eared doves in the region.

\section{MATERIAL AND METHODS}

\section{Study area}

The region studied is just north of the tropic of Capricorn, with land-use as shown in Fig. 1. Southward, near the Paranapanema River, on fertile, well-drained, and deep clay soils of basaltic origin (IPT, 1981a, b), annual crops dominate, mostly soybeans, maize, wheat, and rice, in order of importance. The original vegetation was tropical semideciduous forest, of which only $3 \%$ is left. The northern quarter of the study area, by the Peixe River, is fertile, shallow sandy soils from sandy carbonate mainly devoted to pasture (Marília Formation, Bauru Group).

The landscape is hilly, steep in places, and subject to erosion. Eight percent of the original semi-deciduous tropical vegetation remains. Sandwiched between the two there is a gently hilly central strip, with sandy, deep, highly porous soils of low fertility, derived from the Adamantina Formation (Bauru Group). The original vegetation of this central strip was savannah-like cerrado, of which $6 \%$ is now left.

Elevations range between 320 and $650 \mathrm{~m}$ above sea level. The climate is tropical and humid, with hot summers, infrequent frosts, and rain concentrated in the summer (December-February), Cfa on the Köppen (1931) classification. Data from the weather station of the Companhia Agrícola Nova América (the largest local sugar-cane farm, where the doves breed) show extreme monthly mean temperatures of $26^{\circ} \mathrm{C}$ and $18^{\circ} \mathrm{C}$, in February and June (1975 to 1992 ), and mean of $22.6^{\circ} \mathrm{C}$. Average annual rainfall was $1,353 \mathrm{~mm}$ (1949 to 1992), varying from $199 \mathrm{~mm}$ in December to 45 $\mathrm{mm}$ in August. Surface water is abundant yearround in the region and widely available to wildlife, even if the ground becomes very dry in winter (June-August).

\section{The colony}

The breeding colony (Fig. 1) was at $50^{\circ} 35^{\prime} \mathrm{W}$, $22^{\circ} 47^{\prime} \mathrm{S}$, near Tarumã and on the property of Companhia Agrícola Nova América. The colony, which occupied up to 1,000 ha during the period of this study, had some four million or more breeding birds (Ranvaud, 1999b). Smaller colonies were reported $30 \mathrm{~km}$ south and $50 \mathrm{~km}$ west, and $130 \mathrm{~km}$ north and $55 \mathrm{~km}$ east, in similar landscape situations. 


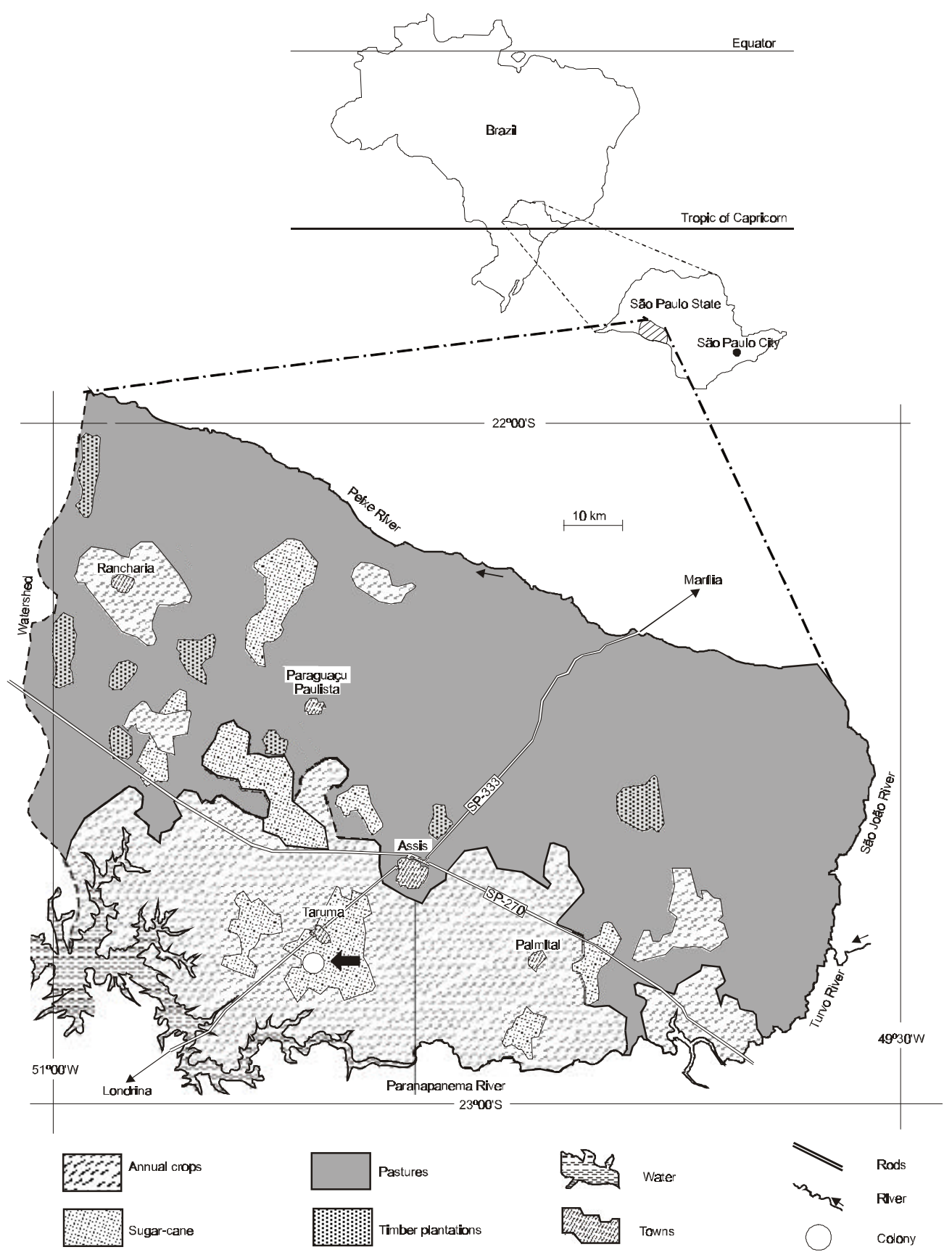

Fig. 1 - Land use in the study region, and location of colony (arrow), protected by a large sugar-cane plantation surrounded by grain areas. Data mid 1980's (Instituto Agronômico, Secretaria do Estado de São Paulo; Carta do Uso da Terra do Estado de São Paulo; Marília, sheet SF-22-Z-A).

The doves nest on the ground, amid the sugarcane stalks. Eggs are laid on bare ground or dead leaves that accumulate as the cane matures, sometimes in a rudimentary nest mostly made of bits of sugar-cane leaf or grass blades.

\section{Procedures}

Between August 1994 and July 1995, 646 doves were collected at different points in the colony in monthly samples of about 50 each. The birds were collected by hand, rushing into the 
sugar-cane with a flashlight in the first hours after dusk. The doves were stored in a freezer for later analysis. In the laboratory, crops were weighed and then emptied, washing food items in running water. Individual crop contents were then dried to constant weight in a ventilated oven, and items sorted, weighed, and stored. Samples were kept for later identification by specialists. Frequency of occurrence was obtained considering only species that constituted at least $3 \%$ of total weight of crop contents, or weighed $>0.1 \mathrm{~g}$. Because of the ecological, economic, and management implications, and following Bucher \& Nores (1976) and Ramakka \& Ramakka (1979), food items were separated in two categories: annual cultivated grains and other seeds, labeled as non-cultivated (or wild, mostly weeds).

\section{RESULTS}

\section{Overall weight and composition of diet}

Monthly average dry weights of dove crops are shown in Fig. 2. Differences between months were significant (one-way analysis of variance, $\mathrm{F}$ $(11 ; 634)=11.05, \mathrm{p}<0.0001)$. November to January crops were light (averaging less than 3.7 g) and Tukey's pairwise comparisons revealed that the lowest mean weight (December) was different from all months except November and January $(\mathrm{p}=$ 0.05 ), thus characterising these as three months of relative hardship. Between February and May crops were intermediate in weight (about $5 \mathrm{~g}$ ). June to October, crops contained the most food (around $7 \mathrm{~g}$ ). Tukey's pairwise comparisons showed that the two highest mean weights (August, October)

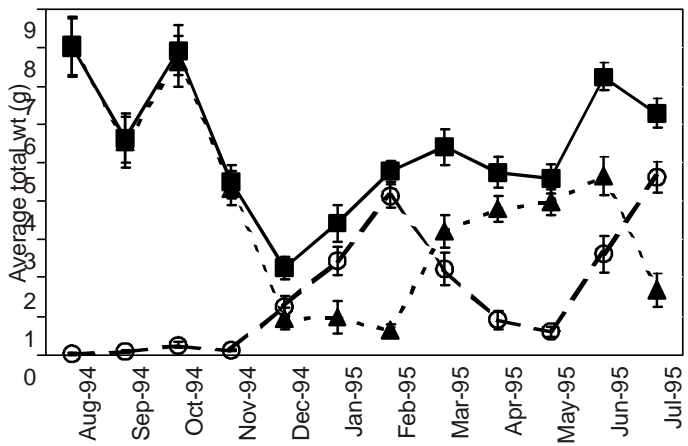

Fig. 2 - Average dry weight of Eared Dove crops in Southeastern Brazil (black squares) divided in cultivated (black triangles) and non-cultivated seeds (white circles). were different from all months except September, June, and July $(\mathrm{p}=0.05)$.

Cultivated grains represented overall $70 \%$ of monthly mean dry weights (an average of $3.70 \mathrm{~g}$ per crop), versus $30 \%$ for wild seeds (average $1.61 \mathrm{~g}$ ). The composition of the diet in terms of these two classes in the period from August 1994 to July 1995 is shown in Figs. 2 and 3. The doves took cultivated grains almost exclusively between August and November and predominantly between April and June, whereas non-cultivated seeds were predominant in January and February, and in July. In December and March each of these classes composed about 50\% of the diet by weight (Fig. 3). Table 1 lists all seeds present in the crops together with overall frequency and percentage weight contribution. Only 12 items were present as more than trace amounts in at least one of the 646 crops inspected. Trace amounts were defined as either $<3 \%$ of crop weight, or $<0.1 \mathrm{~g}$.

\section{Cultivated grain}

As shown in Fig. 4, maize was the most important item among cultivated grains, contributing $66 \%$ of the dry weight of such seeds ( $46 \%$ of total dry weight). It was also the most frequent cultivated grain in ten out of twelve months (August-May) and second in the other two (Fig. 5).

Between August and October maize appeared in over $80 \%$ of the crops and it was the only item found in over $10 \%$ of the doves in all monthly samples analysed. Wheat was second in total weight ( $16.8 \%$ of cultivated grains and $11.8 \%$ of total dry weight), followed by rice $(10.3 \%$ and $7.2 \%)$, and finally soybeans $(6.8 \%$ and $4.8 \%)$. Further quantitative comparisons are shown in Table 1.

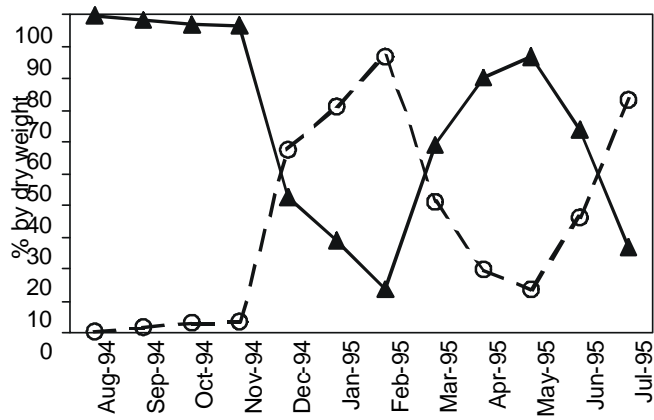

Fig. 3 - Dry weight percentage composition of food ingested by Eared Doves, in terms of cultivated (black triangles) and non-cultivated seeds (white circles) 


\section{TABLE 1}

Seeds encountered in 646 Eared Dove crops collected at a breeding colony in South-eastern Brazil, Aug 94Jul 95. $\mathrm{F}_{\max } / \mathrm{F}_{\min }=$ maximum and minimum frequency of occurrence in monthly samples;

$\%$ dry wt $=$ overall $\%$ by weight of 12 most important seeds; seed mean wt $(\mathrm{mg})=$ obtained averaging 10 groups each weighing $>0.1 \mathrm{~g}$.

\begin{tabular}{|c|c|c|c|c|}
\hline Seeds & $\mathbf{F}_{\max }$ & $\mathbf{F}_{\min }$ & $\%$ dry wt & Seed mean dry wt (mg) \\
\hline \multicolumn{5}{|l|}{ Chenopodiaceae } \\
\hline Chenopodium album & $<1 \%$ & $0 \%$ & - & \\
\hline Chenopodium ambrosioides & $<1 \%$ & $0 \%$ & - & \\
\hline \multicolumn{5}{|l|}{ Amaranthaceae } \\
\hline Amaranthus hybridus & $<1 \%$ & $0 \%$ & - & \\
\hline Amaranthus viridis & $23 \%$ & $0 \%$ & $<1 \%$ & 0.64 \\
\hline \multicolumn{5}{|l|}{ Fabaceae } \\
\hline Glicine $\max$ & $32 \%$ & $0 \%$ & $4 \%$ & 135 (bean); 55.7 (cotyledon) \\
\hline Lathyrus sp. & $<1 \%$ & $0 \%$ & - & \\
\hline Macroptilum atropurpureum & $<1 \%$ & $0 \%$ & - & \\
\hline Vigna mungo & $<1 \%$ & $0 \%$ & - & \\
\hline \multicolumn{5}{|l|}{ Euphorbiaceae } \\
\hline Chamaesyce prostrata & $<1 \%$ & $0 \%$ & - & \\
\hline Chamaesyce serpens & $<1 \%$ & $0 \%$ & - & \\
\hline Croton glandulosus & $15 \%$ & $0 \%$ & $<1 \%$ & 5.63 \\
\hline Euphobia heterophylla & $77 \%$ & $10 \%$ & $15 \%$ & 7.64 \\
\hline Ricinus communis & $<1 \%$ & $0 \%$ & - & \\
\hline \multicolumn{5}{|l|}{ Malvaceae } \\
\hline Sida rhombifolia & $<1 \%$ & $0 \%$ & - & \\
\hline \multicolumn{5}{|l|}{ Sterculiaceae } \\
\hline Waltheria indica & $<1 \%$ & $0 \%$ & - & \\
\hline \multicolumn{5}{|l|}{ Convolvulaceae } \\
\hline Ipomea cynanchifolia & $<1 \%$ & $0 \%$ & - & \\
\hline Ipomea grandifolia & $<1 \%$ & $0 \%$ & - & \\
\hline \multicolumn{5}{|l|}{ Solanaceae } \\
\hline Solanum americanum & $<1 \%$ & $0 \%$ & - & \\
\hline \multicolumn{5}{|l|}{ Brassicaceae } \\
\hline Raphanus raphanistrum & $22 \%$ & $0 \%$ & $<1 \%$ & 6.20 (seed); 12.8 (fruit) \\
\hline \multicolumn{5}{|l|}{ Asteraceae } \\
\hline Ambrosia strigosa & $<1 \%$ & $0 \%$ & - & \\
\hline Blainvillea latifolia & $<1 \%$ & $0 \%$ & - & \\
\hline \multicolumn{5}{|l|}{ Commellinaceae } \\
\hline Commelina benghalensis & $35 \%$ & $0 \%$ & $1 \%$ & 2.56 (seed); 7.11 (fruit) \\
\hline \multicolumn{5}{|l|}{ Poaceae } \\
\hline Avena strigosa & $<1 \%$ & $0 \%$ & - & \\
\hline Brachiaria brizanta & $5 \%$ & $0 \%$ & $2 \%$ & 5.60 \\
\hline Brachiaria plantaginea & $74 \%$ & $2.5 \%$ & $11 \%$ & 4.88 (spikelet); 3.92 (fertile anthecium) \\
\hline Digitaria ciliaris & $<1 \%$ & $0 \%$ & - & \\
\hline
\end{tabular}


TABLE 1 (Continued)

\begin{tabular}{|l|ll|c|c|}
\hline \multicolumn{1}{|c|}{ Seeds } & $\mathbf{F}_{\mathbf{m a x}}$ & $\mathbf{F}_{\mathbf{m i n}}$ & $\mathbf{\%} \mathbf{d r y} \mathbf{w t}$ & Seed mean dry wt (mg) \\
\hline Echinocloa colonum & $<1 \%$ & $0 \%$ & - & \\
\hline Echinocloa crusgalli & $<1 \%$ & $0 \%$ & - & \\
\hline Eleusine indica & $<1 \%$ & $0 \%$ & - & \\
\hline Oryza sativa & $62 \%$ & $0 \%$ & $7 \%$ & \\
\hline Panicum maximum & $<1 \%$ & $0 \%$ & - & \\
\hline Paspalum notatum & $<1 \%$ & $0 \%$ & - & \\
\hline Sorghum almum & $<1 \%$ & $0 \%$ & - & \\
\hline Sorghum bicolor & $<1 \%$ & $0 \%$ & - & \\
\hline Sorghum halepenses & $7 \%$ & $0 \%$ & $<1 \%$ & \\
\hline Triticum aestivum & $55 \%$ & $0 \%$ & $12 \%$ & \\
\hline Zea mays & $82.5 \%$ & $12 \%$ & $46 \%$ & \\
\hline Cyperaceae & \multicolumn{5}{|c|}{233} \\
\hline Cyperus flavus & $<1 \%$ & $0 \%$ & - & \\
\hline Cyperus virens & $<1 \%$ & $0 \%$ & - & \\
\hline Cyperus sp. & $<1 \%$ & $0 \%$ & - & \\
\hline
\end{tabular}

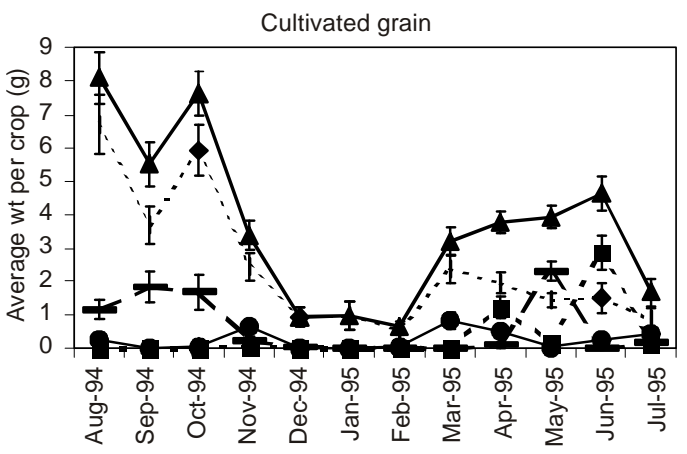

Fig. 4 - Monthly average dry weight of cultivated grain in Eared Dove crops: maize (diamonds), wheat (dashes), rice (squares), and soy beans (circles); total commercial grain weight (black triangles) also shown.

\section{Non-cultivated seeds}

Figs. 6 and 7 show the distribution of noncultivated seeds in the doves' diet through the year. Two species were prominent: Euphorbia heterophylla and Brachiaria plantaginea, providing an alternative source of food at times when cultivated grain was scarce.

These are well known weeds in the region, kept under control with the use of herbicides (Kissmann, 1997). Thus, the doves are likely to find

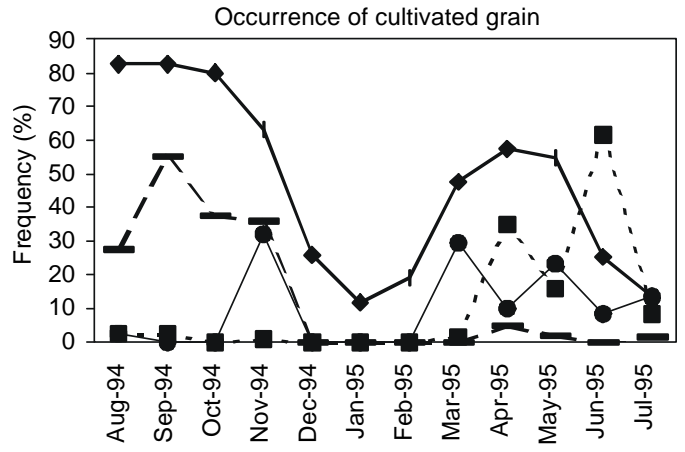

Fig. 5 - Frequency of occurrence of cultivated grain in Eared Dove crops: symbols as in Fig. 4.

this source of food in much the same location as where grain crops are abundant.

\section{Frequency versus weight}

The curves describing dry weight (Fig. 4) and frequency of occurrence (Fig. 5) of cultivated grain showed a very similar shape over the year. In contrast, non-cultivated seeds showed quite different frequency and weight distributions (Figs. 6 and 7). 


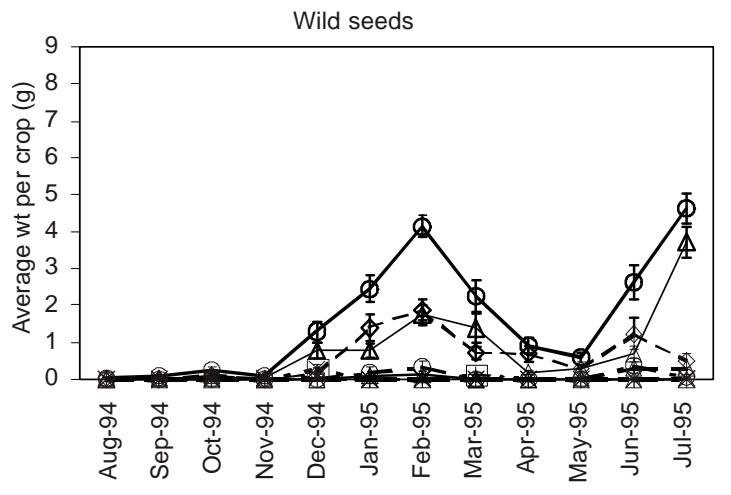

Fig. 6 - Monthly average dry weight of non-cultivated (wild) seeds in Eared Dove crops: Euphorbia heterophylla (white triangles); Brachiaria plantaginea (white diamonds); other curves refer to: Commelina benghalensis, Amaranthus viridis, Croton glandulosus, Raphanus raphanistrum, Sorghum halepense, Brachiara brizanta all of which had much smaller contributions; total wild seeds (white circles).

Particularly striking is the fact that these seeds were found in many crops throughout the period between January and June (Euphorbia heterophylla and Brachiaria plantaginea, in $40 \%$ to $80 \%$ of the crops). Such high frequencies are comparable to or even higher than shown by commercial grain in spite of the much smaller weight, especially in April and May, when non-cultivated seeds constituted only $18.8 \%$ and $11.5 \%$ of crop weight, respectively.

\section{Animal food}

Animal food was sometimes present in the Eared Dove crops (Fig. 8). Doves ingested small snails (Gastropoda), either with planar spiral shells (Biomphalaria sp.), mostly found in wet areas, or with conical spiral shells, more often found on dry land. Parts of millipedes (Diplopoda) were also present on occasion. Most strikingly, in December and January, very many caterpillars and pupae of the moth Anticarsia gemmatalis (velvetbean caterpillar, a serious pest for soybeans in the region) were present. January is a lean month, with relatively few seeds available and low mean crop weights. Up to 88 caterpillars could be counted in a single crop which, like several others, had nothing else in it. Pupae were by far the largest hard item ingested by the doves $(20 \times 6 \mathrm{~mm})$, and as many as 35 pupae could be found in a single crop.

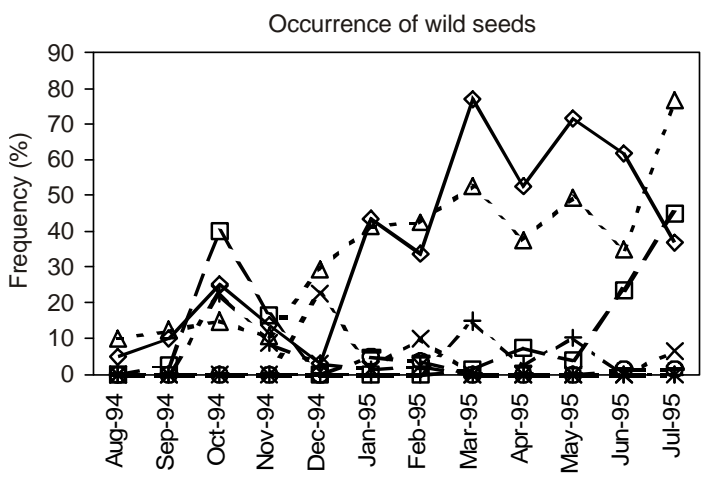

Fig. 7 - Frequency of occurrence of wild seeds in colonial Eared Dove crops: Euphorbia heterophylla (white triangles); Brachiaria plantaginea (white diamonds); Commelina benghalensis (white squares); Amaranthus viridis (x); Croton glandulosus (+); Raphanus raphanistrum (*); Sorghum halepense (maximum frequency in Jan $=6.7 \%$ ); Brachiara brizanta (maximum frequency in $\mathrm{Feb}=3.8 \%$ ).

\section{DISCUSSION AND CONCLUSIONS}

The focus of attention in relation to Eared Dove biology in the study region was the environmental carrying capacity for such a dense population. The analysis of the doves' diet was therefore carried out with emphasis first on the weight of items present in the crops and, second, on the frequency of occurrence rather than more indirect measures of importance such as number of items.

\section{Cultivated grain versus non-cultivated seeds}

Cultivated grain crops dominated the Eared Dove's diet throughout the year, except for the four months between December and March, and in July. Spring and early summer (November-January) coincide with the beginning of rains, a time when most of the grain crops are sown, and therefore unavailable for the doves.

At the same time, pastures and wild seeds may be found, although at low densities, in recently ploughed fields or in pastures and abandoned fields where some species may already be fruiting. Euphorbia heterophylla, Brachiaria plantaginae, and Commelina benghalensis are considered serious weeds in the region, especially for soybeans (Kissmann, 1997). 


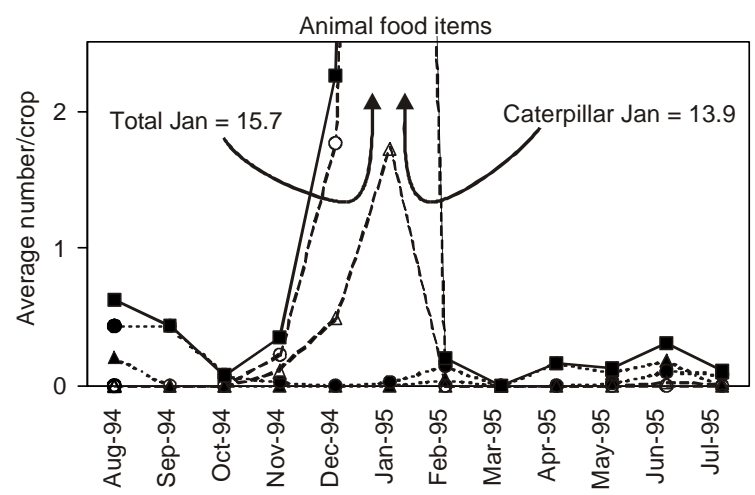

Fig. 8 - Distribution of animal food items in the crops of the doves: Velvetbean catterpillars (white circles); Velvetbean pupae (white diamonds); conical spiral snails (black diamonds), and planar spiral snails (black circle); total animal items per crop (black squares).

Thus, cultivated grain and this alternative source of food are found in largely the same locations and are associated with the same human activities.

Between April and June wild seeds were remarkably frequent (55\%-75\%, Fig. 7) in spite of low total weight (15\%-35\%, Fig. 3), whereas commercial crops showed comparable frequencies and weights (respectively 55\%-65\%, Fig. 5; 65\%$85 \%$, Fig. 3).

This is consistent with the much smaller size and weight of wild seeds. As can be inferred from Table 1, among the 12 dominant items cultivated grains are between 3.2 and 91 times as heavy as noncultivated seeds. Differences in availability and/ or in the dove's preference may have played an important role in determining the different weight and frequency distributions. The continued high frequency in this period could indicate that noncultivated seeds were widely available and that doves generally took them. However, their relatively small participation in the weight composition of the diet suggests that the birds were unable or unwilling to take large volumes of wild seed.

Birds that had access to commercial grain, on the other hand, were willing able and to ingest relatively large quantities. Weed seeds are common in cultivated fields, although not as abundant as cultivated grain. They can thus be "sampled" by the birds while feeding on cultivated seeds. An alternative explanation might be that weeds are more widely distributed, so doves will find them (usually at low density) wherever they start feeding. However, if the more profitable cultivated seeds are present, the birds will prefer those, taking only small amounts of wild seeds before leaving the unproductive areas or switching to grain crops.

After February, availability of cultivated seeds increases rapidly as the crops mature and are harvested. A second peak of cultivated seed becomes available between August and November, resulting from a second harvest of some crops, particularly maize and wheat. The availability of maize most probably results from a combination of three factors. First, the area dedicated to this crop was large during the study period (13\% of the stippled area in Fig. 1, for the summer harvest). Second, as stated above, it is locally common practice, especially since the mid eighties, to produce a second (winter) harvest each year (known locally as "safrinha") in addition to the traditional summer harvest. Finally, often large amounts of waste grain are left in the fields by harvesting machines. Associating these three factors, it is easy to understand how large quantities of the food we found in the doves' crops were available to the birds almost year-round.

\section{Animal food}

Animal items in the diet present two interesting aspects. Velvetbean caterpillars and pupae must have been taken in soybean fields, where plant items abundant in the doves' diet were present at other times of the year. Thus, doves apparently visited the same fields at different times of the year, exploiting widely different sources of food accor- 
ding to seasonal availability. Pupation in Anticarsia gemmatalis occurs mostly underground, and since doves are not known to scratch or dig for food, the fact that they ate velvetbean pupae is very curious.

However rain (very abundant in January) and other factors can wash off the shallow layer of soil that covers some of the pupae, and thus make a small fraction of them available to the doves at a time when relatively little else is.

\section{Comparison with other situations}

If we compare our results on the diet of Eared Doves in NE Brazil and the annual cycle of their feeding habits with data from central Argentina and the Cauca Valley of Colombia, interesting parallelisms and differences become evident. In Argentina and Colombia, doves were reported to take mostly commercial grain (> $72 \%$ by dry weight in all months in Argentina, Bucher \& Nores, $1976 ;>79 \%$ by volume in all months in Colombia, Ramakka \& Ramakka, 1979). In the Brazilian NE, on the other hand, the doves took almost exclusively wild seeds (Aguirre, 1976; Azevedo Junior \& Antas, 1990). In contrast, both of these were important in our study area. Pasture and wild seeds substituted cultivated grain as these became scarce in June and July and even more in December and January. These were months of less abundance of doves in the region, and very little if any breeding at the colony (Menezes et al., 1998). There was a noticeable difference between the diet in the two reproductive seasons. In the August to November season, the incidence of cultivated grain was so great as to almost exclude other seeds (more than $96 \%$ by weight, which is more than any month in Córdoba, according Table 1 in Bucher \& Nores, 1976). In the February to May breeding peak, weed seeds were taken much more often, and, more significantly, reproduction was initiated in early February, a time when non-cultivated seeds were dominant.

\section{Origin of the colony in the study area}

The doves' diet is consistent with a scenario in which the origin and permanence of the colony in the study area are the result of a process such as that described by Bucher (1990). A favourable combination of two factors appears to have been crucial in increasing substantially the system's carrying capacity for doves in the region. The first is large-scale food availability almost year-round resulting from changes in local agricultural practices, with increased areas devoted to annual crops, much waste left in the fields, and two yearly harvests. The second is the remarkable adoption of sugar-cane plantations as a suitable habitat for colonial breeding. Elsewhere, colonies occurred only in thorny, semiarid vegetation. Thus Eared Doves in South-eastern Brazil, show a number of interesting "innovations" in several details of their breeding and feeding habits.

Acknowledgments - Our special thanks go to Prof. Doris Groth, (Feagri, University of Campinas, SP), to Prof. Flávio Moscardi (CNPSo-Embrapa, Londrina, PR), and to Prof. Osmar Domaneschi (Instituto de Biociências, University of São Paulo, SP) for their identification, respectively, of the seeds, the velvetbean caterpillar and pupae, and the snails found in the doves' crops. We are grateful to Daniel Baratela for his indispensable participation in collecting the birds analyzed in this study. We also thank José Gilberto Milani, and Eva Cristina Aurélio Menezes for help during analysis of the crops, and Julia Pavan Soler for help with the statistics. This work would not have been possible without the cooperation and support of the Director of the Companhia Agrícola Nova America, José Eugênio de Rezende Barbosa.

\section{REFERENCES}

AGUIRRE, A. C., 1976, Distribuição, costumes e extermínio da "avoante" do nordeste, Zenaida auriculata noronha Chubb. Academia Brasileira de Ciências, Rio de Janeiro, $35 \mathrm{p}$.

AZEVEDO JUNIOR, S. M. \& ANTAS, P. T. Z., 1990, Novas informações sobre a alimentação de Zenaida auriculata no Nordeste do Brasil. Anais do IV Encontro Nacional de Anilhadores de Aves, Universidade Federal Rural de Pernambuco, Recife (1988), pp. 59-64.

BRUGGERS, R. L. \& ELLIOTT, C. C. H., 1989, Quelea quelea, Africa's Bird Pest. Oxford University Press, Oxford, 402p.

BUCHER, E. H., 1982, Colonial breeding of the Eared Dove (Zenaida auriculata) in North-eastern Brazil. Biotropica, 14: 255-261.

BUCHER, E. H., 1990, The influence of changes in regional land-use patterns on Zenaida Dove populations. pp. 291303. In: J. Pinowski \& J. D. Summers-Smith (eds.), Granivorous birds in the agricultural landscape. Polish Academy of Science, Warsaw.

BUCHER, E. H. \& ORUETA, A., 1977, Ecologia de la reproducción de la paloma Zenaida auriculata. II. Época de cría, suceso y productividad en las colonias de nidificación de Córdoba. Ecosur, 4: 157-85.

BUCHER, E. H. \& NORES, M., 1976, Ecologia de la alimentación de la paloma Zenaida auriculata. Physis Secc. C., 35: 17-32. 
DONATELLI, R. J., ANDRELA, S. \& SANTOS, R., 1995, Uma metodologia para tentar minimizar o impacto de $Z e$ naida auriculata (Aves, Columbiformes) sobre as áreas de cultivo de grãos na região sudoeste do Estado de São Paulo. Salusvita, 14(1): 21-29.

IPT (Instituto de Pesquisa Tecnológica), 1981a, Mapa Geológico do Estado de São Paulo, Vols. I, II.

IPT (Instituto de Pesquisa Tecnológica), 1981b, Mapa Geomorfológico do Estado de São Paulo, Vols. I, II.

KISSMANN, K. G., 1997, Plantas Infestantes e Nocivas. 2. ed. Basf S.A., São Bernardo do Campo, SP, Brasil, Vol. $1,824 \mathrm{p}$.

KÖPPEN, W., 1931, Grundriss der Klimakunde. Walter de Gruyter \& Co., Berlin.

LACK, D., 1968, Population studies of birds. Clarendon Press, Oxford, 341p.

MENEZES, L. N., RANVAUD, R. D. \& BUCHER, E. H., 1998, Breeding synchronization in Eared Dove Zenaida auriculata colonies in South-eastern Brazil. In: N. J. Adams \& R. H. Slotow (eds.), Proc. 22 Int. Ornithol. Congr., Durban. Ostrich, 69: 227.

MURTON, R. K., BUCHER, E. H., NORES, M., GOMEZ, E. \& REARTES, J., 1974, The ecology of the Eared Dove (Zenaida auriculata) in Argentina. Condor, 76: 80-88.

MURTON, R. K. \& WESTWOOD, N. J., 1977, Avian breeding cycles. Clarendon Press, Oxford, 594p.

RAMAKKA, J. M. \& RAMAKKA, V. R., 1979, Eared Dove food habits in southeastern Colombia. J. Wildl. Manage, 43: 534-540.

RANVAUD, R., 1999a, Avaliação do projeto experimental de controle 1993-1994. In: Simpósio sobre a Biologia e o Manejo da Pomba-Amargosa, Zenaida auriculata. Assis, SP, 23/24 setembro de 1999. Programa, Resumos $e$ Conclusões, pp. 10-11. Available through cidambiental@mma.gov.br.
RANVAUD, R., 1999b, Extensão, população e dinâmica populacional da colônia reprodutiva em Tarumã: 1998-1999. In: Simpósio sobre a Biologia e o Manejo da PombaAmargosa, Zenaida auriculata. Assis, SP, 23/24 setembro de 1999, Programa, Resumos e Conclusões, pp. 11-12. Available through cid-ambiental@mma.gov.br.

REZENDE, M. A., 1987a, Relatório das expedições do Projeto Amargosa. Relatório Interno, Associação Brasileira de Caça e Conservação. 21p. Available through www.safariclubbrasil.org or rfreire@safariclubbrasil.org.

REZENDE, M. A., 1987b, Projeto de uma proposta para uma temporada de caça experimental na Zona Administrativa de Ribeirão Preto, Estado de São Paulo. 7p. Available through www.safariclubbrasil.org or rfreire@safariclubbrasil.org.

REZENDE, M. A., 1987c, A ocupação de Zenaida auriculata no Estado de São Paulo e estados vizinhos. Relatório Interno, Associação Brasileira de Caça e Conservação. 9p. Available through www.safariclubbrasil.org or rfreire @ safariclubbrasil.org.

VALENCIA, G. D., RAMAKKA, J. M. \& RAMAKKA, V. F., 1976, Biología y control de daño de la torcaza naguiblanca (Zenaida auriculata) en el Valle del Cauca, Colombia. Instituto Colombiano Agropecuario, Centro Experimental Palmira, 40p. 